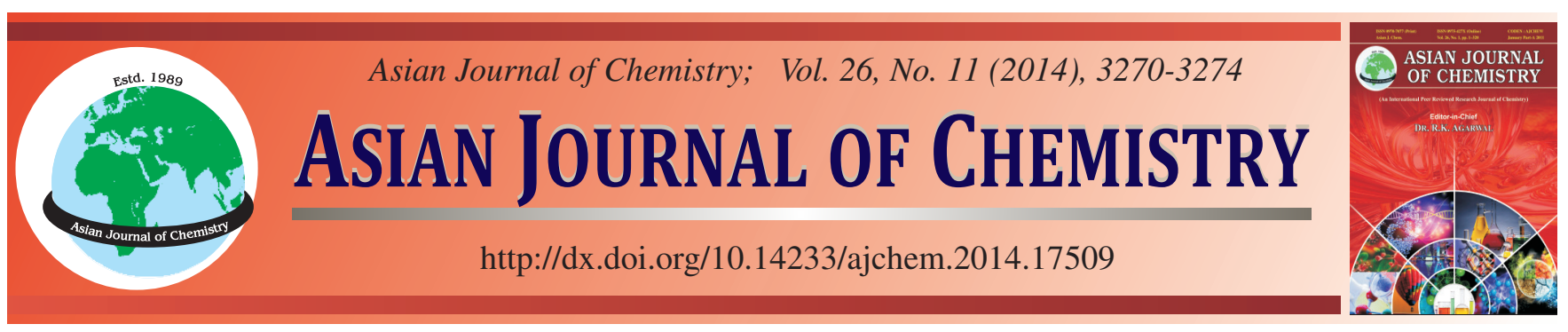

\title{
Mechanisms of Generation of Biogenic Methane Influenced by Types of Strain and Disodium EDTA
}

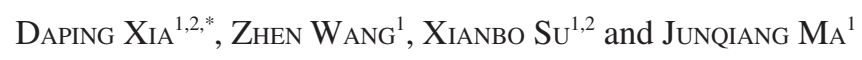

${ }^{1}$ School of Energy Science and Engineering, Henan Polytechnic University, Jiaozuo 454000, P.R. China

${ }^{2}$ State Key Laboratory Cultivation Base for Gas Geology and Gas Control, Jiaozuo 454000, P.R. China

*Corresponding author: E-mail: 569689819@qq.com

Received: 5 February 2014;

Accepted: 10 April 2014;

Published online: 25 May 2014;

AJC-15230

In adoption of plate isolation, anaerobic culture and PCR amplification techniques, a methanogens-culture experiment was conducted for investigating the mechanisms of generation of biogenic methane, during which coals of Shaqu colliery were used as substrates and mine water collected from Zhongtai and Shaqu collieries, respectively. The white-rot fungi preserved in laboratory were utilized as strain sources. Methane production was fully examined with the addition of disodium EDTA under various concentration gradients. The results show that there are methanogens present in mine water of Zhongtai, while the growth of methanogens in mine water of Shaqu is possibly discouraged due to the tested existence of denitrifying bacteria and overhigh $\mathrm{pH}$. Hence, there is no methane being produced from coals of Shaqu as compared to the occurrence of gaseous production from that of Zhongtai under the same conditions. Meanwhile, when disodium EDTA is added at $1 \mathrm{~g} / \mathrm{L}$ can the $\mathrm{CH}_{4}$ production reach a peak of $10 \mathrm{~mL} / \mathrm{g}$ after a period of increase and the $\mathrm{pH}$ value can also see a notable rise after reaction.

Keywords: Methanogens, Biogenic methane, Disodium EDTA, Gaseous production.

\section{INTRODUCTION}

Biogenic methane, produced initially and developed successfully form Powder River Basin and San Juan Basin, USA, has made people gradually aware of the great significance bio-generated methane could play in the increase of coal bed methane (CBM) resources ${ }^{1}$. So far substantial studies have been focused on biogenic methane $\mathrm{e}^{2-6}$ and the microbes that create it, which have in some cases been evidenced by a series of laboratory experiments where coals can be converted into gaseous fuels (mainly methane) through biodegradation ${ }^{7-10}$.

Methanogens are considered as the key driver for biological generation of methane ${ }^{11-14}$, thus the types and quantities of methanogens needed in bio-generation process are not only regarded as the fundamental research subjects of biogenic methane, but as a great support for the research on the heredity and breeding of methanogens and the corresponding biophysical and biochemical properties of them.

To investigate the impact of methanogens on coal fermentations to evolve biogenic gases and further to study the mechanisms and contributing factors responsible for biologically-generated methane ${ }^{15}$, withe-rot fungi and anaerobic microbial consortia originated in mine water were used as strain sources in this experiment and through the enrichment and identification of indigenous microbial of mine water, the traits of its growth and reproduction ${ }^{16}$ were studied. Additionally, disodium EDTA was used to treat coal samples with high content of heavy metals ${ }^{17,18}$, by which the metabolic activities of microbial in the anaerobic fermentation system were activated, further the function of microbial was evidenced.

\section{EXPERIMENTAL}

Coal substrates: Differing from previous work ${ }^{19}$, highgrade bituminous coal samples selected, respectively from Shaqu colliery of Huajin Coking Coal Co., Ltd., Shanxi Province and from Zhongtai colliery of Hebi Coal Co., Ltd, Henan Province were applied in the experiments as coal substrates. Coal samples were grounded into powders to the size of 6080 mesh using a grinder in laboratory prior to being sterilized in an automatic autoclave at $121^{\circ} \mathrm{C}$ for $0.5 \mathrm{~h}$ and then being dried and reserved for use.

Strain sources: (1) White-rot fungi were provided by the Biology Technology Laboratory, Henan Polytechnic University, after being inoculated onto the potato-dextrose-agar (PDA) slant medium they were preserved in a refrigerator at $4{ }^{\circ} \mathrm{C}$; (2) 
Microbial consortia for anaerobic fermentation were sampled from the mine water of Shaqu and Zhongtai collieries, respectively, derived from the drainage ditches in the mining working face and packed with axenic plastic buckets. A quick seal should be guaranteed before being brought back to the lab and reserved in a refrigerator at $4{ }^{\circ} \mathrm{C}$.

Medium: (1) Medium for the enrichment of white-rot fungi; (2) Medium for the enrichment of methanogens: $\mathrm{L}_{1} 1.0 \mathrm{~g}$, $\mathrm{S}_{1} 0.4 \mathrm{~g}, \mathrm{~L}_{2} 4.0 \mathrm{~g}, \mathrm{~J} 1.0 \mathrm{~g}, \mathrm{~L}_{3} 0.1 \mathrm{~g}, \mathrm{Y} 1.0 \mathrm{~g}, \mathrm{~L}_{4} 0.5 \mathrm{~g}$, mine water $1000 \mathrm{~mL}$; (3) Medium for the isolation and enumeration of denitrifying bacteria (BTB medium): $\mathrm{KNO}_{3} 1.0 \mathrm{~g}, \mathrm{CH}_{3} \mathrm{COONa}$ $1.0 \mathrm{~g}, \mathrm{KH}_{2} \mathrm{PO}_{4} 1.0 \mathrm{~g}, \mathrm{FeCl}_{2} 0.05 \mathrm{~g}, \mathrm{CaCl}_{2} 0.2 \mathrm{~g}, \mathrm{MgSO}_{4} 1.0 \mathrm{~g}$, BTB $1.0 \mathrm{~mL}(1 \%$, dissolved in alcohol), agar $20.0 \mathrm{~g}$, ultrapure water $1 \mathrm{~L}, \mathrm{pH} \approx 7.3$.

Experimental equipments: The equipments involved in the experiments include automatic autoclave, multifunctional intelligent anaerobic system, electro-thermal incubator, anaerobic workstation, X-ray diffractometer, gas chromatograph, inverted fluorescence microscope, high-speed tabletop centrifuge, etc. The experimental device as shown in Fig. 1 was used to collect the gaseous products.

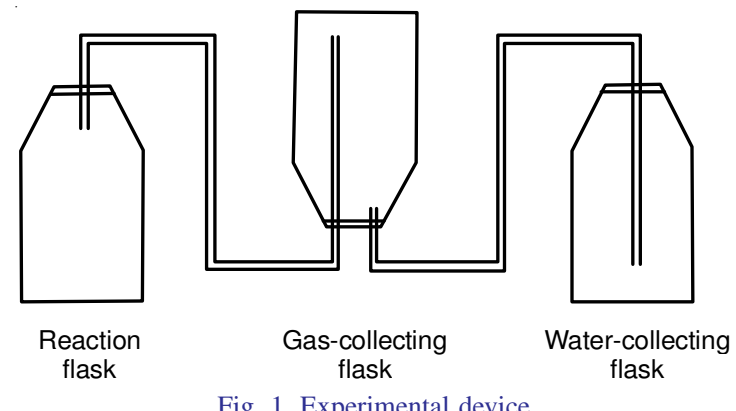

\section{Experimental methods}

Identification of methanogens: Species-specific PCR method was adopted for a quick identification of methanogens in mine water including the following procedures: (1) Culture: Medium was prepared and sterilized in an automatic autoclave at $121^{\circ} \mathrm{C}$ for $20 \mathrm{~min}$ first before being divided equally into 34 culture dishes; mine water was inoculated onto the medium in an anaerobic environment and spread evenly by a sterilized spreader; $\mathrm{N}_{2}$ was introduced for the displacement of $\mathrm{O}_{2}$ within the dishes prior to being placed in an incubator chamber at 35 ${ }^{\circ} \mathrm{C}$ for 10-20 days of methanogens growth. (2) DNA extraction: Already-formed microbial colonies on the medium were slowly rinsed off the surface with a trace amount of anaerobic ultrapure water to make them into $2 \mathrm{~mL}$ centrifuge tubes; OD (optical density) values were determined through a spectrophotometer at the wavelength of $600 \mathrm{~nm}$. To meet the requirements of DNA extraction kits, anaerobic ultrapure water was used to regulate the concentration of OD value at around $1.0 \times 10^{9}$. (3) PCR amplification: a specific primer of 16SrDNA: Met 83F (5V-ACKGCTCAGTAACAC-3V), Met 1340R (5VCGGTGTGTGCAAGGAG-3V) was used for the amplification of object genes of methanogens ${ }^{20}$.

PCR amplification system: $10 \times$ Taq polymerase reaction buffer $2.5 \mu \mathrm{L}$; dNTP (20 mmol/L) $2.5 \mu \mathrm{L} ; 5$ ' -end primer (25 pmol $/ \mu \mathrm{L}) 1 \mu \mathrm{L} ; 3$ '-end primer $(25 \mathrm{pmol} / \mu \mathrm{L}) 1 \mu \mathrm{L} ; \mathrm{Mg}^{2+}(2.5$
mmol/L) $2 \mu \mathrm{L}$; DNA template $1 \mu \mathrm{L}$; Taq DNA polymerase (5U/ $\mu \mathrm{L}) 0.2 \mu \mathrm{L}$; dd $\mathrm{H}_{2} \mathrm{O} 14.8 \mu \mathrm{L}$; total volume $25 \mu \mathrm{L}$.

Conditions: Pre-denaturation for $3 \mathrm{~min}$ at $94^{\circ} \mathrm{C}$; denaturation for $30 \mathrm{~s}$ at $94^{\circ} \mathrm{C}$; renaturation for $30 \mathrm{~s}$ at $58^{\circ} \mathrm{C}$; extension for $90 \mathrm{~s}$ at $72{ }^{\circ} \mathrm{C}$; extension for $10 \mathrm{~min}$ at $72^{\circ} \mathrm{C}$ after 30 cycles. All these procedures should be conducted within the PCR instrument.

Isolation and enumeration of denitrifying bacteria: Dilution spread plate method was introduced to enumerate denitrifying bacteria in mine water. Already-inoculated medium was placed into an incubator chamber at $35^{\circ} \mathrm{C}$ and some single colonies observed with an appearance of a blue aureola after 3-4 days would be identified as denitrifying bacteria.

Methane-production experiment with strain sources from mine water of Shaqu colliery: The Shaqu coals, mine water of Shaqu and white-rot fungi were used as materials (Table-1). By the addition of disodium EDTA under various concentration gradients into the medium, methane-production laws were further studied.

\begin{tabular}{ccccc}
\multicolumn{5}{c}{ TABLE-1 } \\
MATERIALS APPLIED IN METHANE-PRODUCTION \\
EXPERIMENT OF SHAQU COLLIERY
\end{tabular}

Methane-production experiment with strain sources from mine water of Zhongtai colliery: The Shaqu coals, mine water of Zhongtai and white-rot fungi were used as materials (Table2 ). By the addition of disodium EDTA under various concentration gradients into the medium, methane-production laws were studied.

\begin{tabular}{ccccc}
\multicolumn{5}{c}{ TABLE-2 } \\
MATERIALS APPLIED IN METHANE-PRODUCTION \\
EXPERIMENT OF ZHONGTAI COLLIERY
\end{tabular}

Analytical items and testing methods: (1) Identification of methanogens: The products of PCR amplification and loading buffer were mixed and then subjected to gel electrophoresis in $2 \%$ agarose gel before comparing to a DNA maker. The presence of a bright DNA band at 1200 bp would suggest the existence of methanogens in tested mine water, otherwise no methanogens are there. (2) Determination of gas production: The gaseous products derived from the fermentation would be determined by the measurement of amount of water drained off through the experimental device in Fig. 1. (3) Analysis of gas composition and concentration: Analysis of composition and concentration of fermentation-produced gas can be based on the interpretation of gas chromatograph equipped with a TCD detector. (4) Isolation and enumeration 
of denitrifying bacteria: Given the fact that denitrifying bacteria are capable of secreting a large amount of alkaline substances while growing up, BTB medium was used and dilution spread plate method was adopted.

\section{RESULTS AND DISCUSSION}

Results of gas production with strain sources from Shaqu colliery: Gas components and concentrations of each samples produced by fermentation were tested after 40 days as tabulated in Table-3.

Table- 3 showed that none of samples had the production of $\mathrm{CH}_{4}$. Further the mine water of Shaqu was identified by means of species-specific PCR method in contrast to the mine water of Zhongtai. Fig. 2 shows the results of DNA amplification through gel electrophoresis.

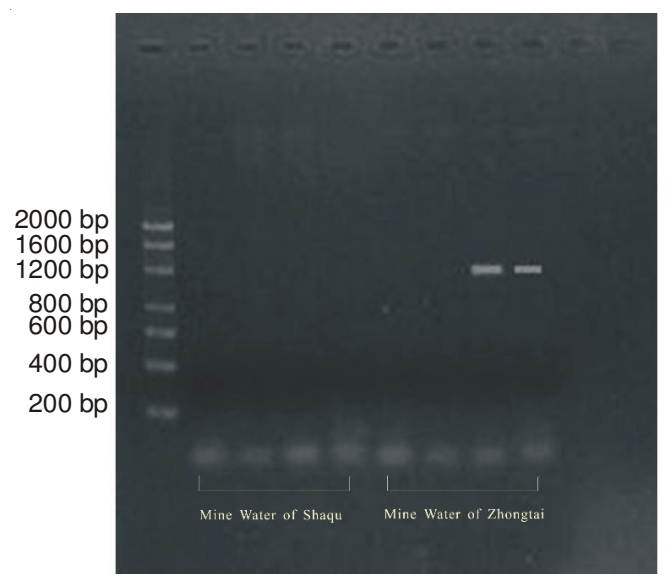

Fig. 2. Result of PCR amplification

As can be seen from Fig. 2, the strain sources originated in mine water of Zhongtai colliery was observed as presenting a specific DNA band at $1200 \mathrm{bp}$ which was indicative of the existence of methanogens after DNA extraction and PCR amplification, while for mine water of Shaqu no such a band was found.

The results indicate the presence of methanogens in mine water of Zhongtai and the absence of methanogens in mine water of Shaqu, so that it is not surprising to note that no methane produced from any of the samples of Shaqu in this experiment.

Table- 3 indicates that despite none of samples had the production of methane, yet a large amount of $\mathrm{N}_{2}$ was produced from all the samples, particularly the highest of $10.5 \mathrm{~mL} / \mathrm{g}$ produced from sample $A_{2}$. This is mainly due to the denitrification of denitrifying bacteria in mine water during anaerobic fermentation, thereby resulting in the significant production of $\mathrm{N}_{2}$. The denitrifying bacteria in mine water of Shaqu were enumerated at $1.75 \times 10^{3}$. The specific growth conditions of denitrifying bacteria at different concentrations of dilution were also as shown in Fig. 3.

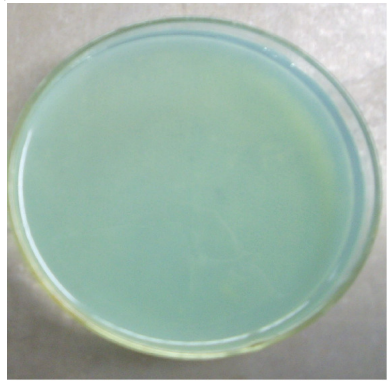

(a) no inoculation

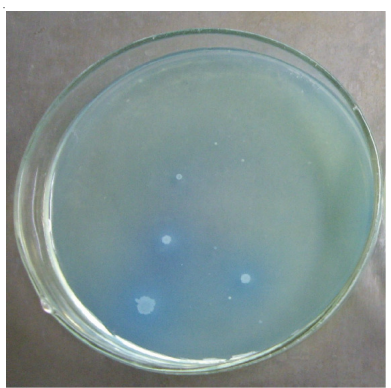

(c) dilution 1:100

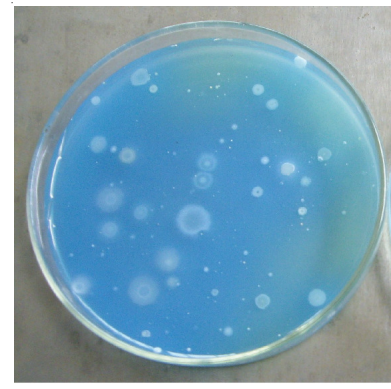

(b) dilution 1:10

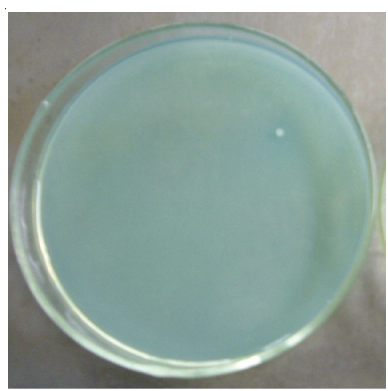

(d) dilution 1:1000
Fig. 3. Growths of denitrifying bacteria under various dilutions

The morphology of denitrifying bacterial colonies under an inverted fluorescence microscope were also observed as pictured in Fig. 4 including spherical and rod-shaped colonies, respectively.

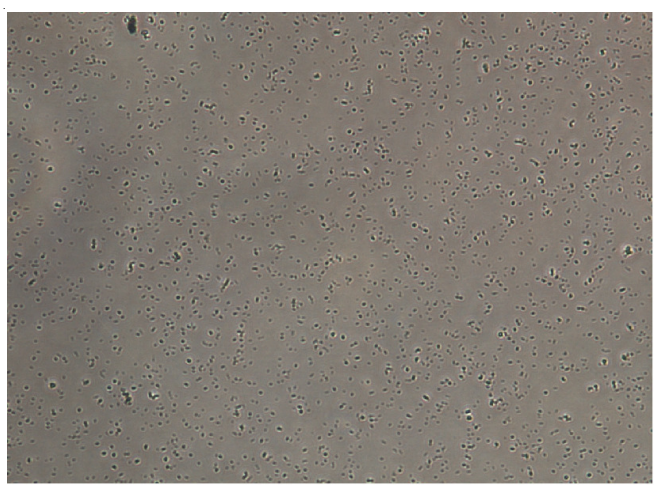

Fig. 4. Morphologies of denitrifying bacteria observed under microscope

Results of gas production with strain sources from Zhongtai colliery: Gas components and concentrations of each samples produced by fermentation were tested after 40 days as given in Table-4.

\begin{tabular}{cccccccc}
\hline \multicolumn{7}{c}{ TABLE-3 } \\
\cline { 3 - 7 } Sample & Disodium & \multicolumn{7}{c}{ Results } \\
\cline { 2 - 7 } & EDTA $(\mathrm{g} / \mathrm{L})$ & $\mathrm{H}_{2}(\%)$ & $\mathrm{CH}_{4}(\%)$ & $\mathrm{CO}_{2}(\%)$ & $\mathrm{N}_{2}(\%)$ & Total $(\mathrm{mL})$ & $\mathrm{CH}_{4}$ production $(\mathrm{mL} / \mathrm{g})$ \\
\hline $\mathrm{A}_{1}$ & 0.0 & 0.00 & 0.0 & 6.0 & 94.0 & 73 & 3.1 \\
$\mathrm{~A}_{2}$ & 1.0 & 0.03 & 0.0 & 1.1 & 98.9 & 237 & 10.5 \\
$\mathrm{~A}_{3}$ & 2.0 & 0.00 & 0.0 & 6.4 & 93.6 & 40 & 1.9 \\
$\mathrm{~A}_{4}$ & 3.0 & 0.02 & 0.0 & 9.4 & 91.6 & 38 & 1.7 \\
\hline
\end{tabular}


TABLE-4

RESULTS OF GAS PRODUCTION FOR ZHONGTAI

\begin{tabular}{|c|c|c|c|c|c|c|c|}
\hline \multirow{2}{*}{ Sample } & \multirow{2}{*}{$\begin{array}{c}\text { Disodium } \\
\text { EDTA }(\mathrm{g} / \mathrm{L})\end{array}$} & \multicolumn{6}{|c|}{ Results } \\
\hline & & $\mathrm{H}_{2}(\%)$ & $\mathrm{CH}_{4}(\%)$ & $\mathrm{CO}_{2}(\%)$ & $\mathrm{N}_{2}(\%)$ & Total $(\mathrm{mL})$ & $\mathrm{CH}_{4}$ production $(\mathrm{mL} / \mathrm{g})$ \\
\hline $\mathrm{B}_{1}$ & 0.0 & 0.00 & 31.5 & 10.4 & 58.1 & 166 & 2.6 \\
\hline $\mathrm{B}_{2}$ & 1.0 & 0.10 & 70.7 & 6.5 & 22.8 & 284 & 10.0 \\
\hline $\mathrm{B}_{3}$ & 2.0 & 0.03 & 56.0 & 10.7 & 33.3 & 278 & 7.8 \\
\hline $\mathrm{B}_{4}$ & 3.0 & 0.02 & 49.0 & 8.9 & 42.0 & 260 & 6.4 \\
\hline
\end{tabular}

Fig. 5 showed the strain sources from mine water of Zhongtai saw a production of $\mathrm{CH}_{4}$ which increased at the beginning and then decreased with the rising concentrations of EDTA. As shown in Table-4, the production of $\mathrm{CH}_{4}$ peaked at $10 \mathrm{~mL} / \mathrm{g}$ when EDTA was $1 \mathrm{~g} / \mathrm{L}$, which was nearly 3.8 times greater than that of when EDTA was absent. Presumably, a moderate amount of EDTA added in use can improve the production of $\mathrm{CH}_{4}$ to a great extent.

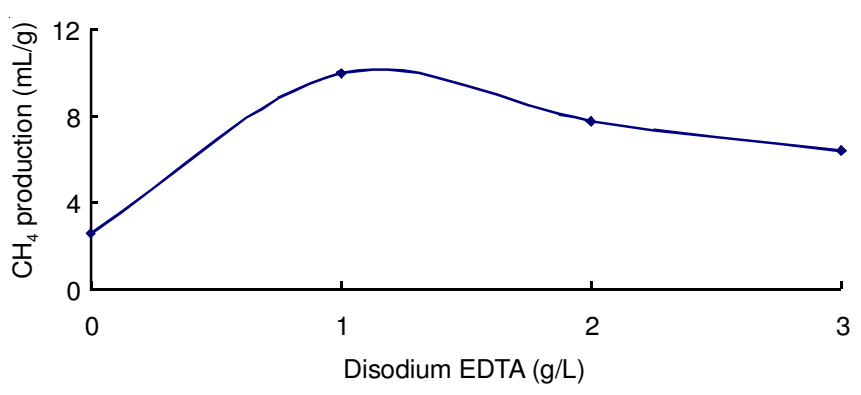

Fig. 5. Relation between disodium EDTA and $\mathrm{CH}_{4}$ production

Hence, disodium EDTA is able to maintain the equilibrium of heavy-metal ions in solutions, making the concentration of heavy-metal ions neither too low to weaken the metabolic activities of microbial nor too high to exhibit a toxic inhibition to the their growth. In addition, as can be indicated from Table4, when EDTA was beyond $1.0 \mathrm{~g} / \mathrm{L}$, the production of $\mathrm{CH}_{4}$ experienced a decreasing trend as a sign of negative inhibition exhibited from EDTA resulting from its complexation with heavy-metal ions on the surface of microbial cell membrane and further causing the death of microbial.

As given in Table-4, a relative high proportion of $\mathrm{N}_{2}$ sustained which was caused by the metabolism of denitrifying bacteria. Dilution spread plate method was adopted to isolate and enumerate the denitrifying bacteria in mine water of Zhongtai and the result was $8.50 \times 10^{2}$, which was far lower than that of in mine water of Shaqu.

Analyses of $\mathrm{pH}$ in solutions before and after fermentation: Table-5 displays the changes of $\mathrm{pH}$ value of each samples tested before and after fermentation.

\section{TABLE-5}

\begin{tabular}{cccc}
$\mathrm{pH}$ VALUES IN SOLUTIONS BEFORE AND AFTER REACTION \\
\hline Sample & $\begin{array}{c}\mathrm{pH} \text { before } \\
\text { reaction }\end{array}$ & $\begin{array}{c}\mathrm{pH} \text { after } \\
\text { reaction }\end{array}$ & $\begin{array}{c}\text { Variations of } \\
\mathrm{pH}\end{array}$ \\
\hline $\mathrm{A}_{1}$ & 7.05 & 8.41 & 1.36 \\
$\mathrm{~A}_{2}$ & 7.05 & 8.44 & 1.39 \\
$\mathrm{~A}_{3}$ & 7.00 & 8.40 & 1.40 \\
$\mathrm{~A}_{4}$ & 7.04 & 8.53 & 1.49 \\
$\mathrm{~B}_{1}$ & 6.97 & 8.01 & 1.03 \\
$\mathrm{~B}_{2}$ & 7.00 & 8.08 & 1.08 \\
$\mathrm{~B}_{3}$ & 7.01 & 8.13 & 1.12 \\
$\mathrm{~B}_{4}$ & 6.98 & 8.16 & 1.18
\end{tabular}

Table-5 showed that there was a notable increase of $\mathrm{pH}$ values for all the tested samples before and after fermentation ${ }^{15}$. The main causes can be analyzed as follows: First, denitrifying bacteria and methanogens can use such acidic substances as formic acid, acetic acid and propionic acid, etc., which are all derived from the coals degradation as carbon sources by fermentation-hydrolysis bacteria for their metabolism and growth, therefore the degree of acidification in ultimate solutions is declined. Second, methanogens are able to utilize part of $\mathrm{CO}_{2}$ generated during the fermentation process to produce $\mathrm{CH}_{4}$ through reduction. Third, denitrifying bacteria will secrete a great deal of alkaline substances further causing the increase of $\mathrm{pH}$ in solutions.

Variations of gaseous products during the experiment: The gaseous products from sample $\mathrm{A}_{2}$ of Shaqu and those from sample $\mathrm{B}_{2}$ of Zhongtai all experienced a whole-process monitor on the variations of gaseous concentrations as portrayed in Fig. 6.

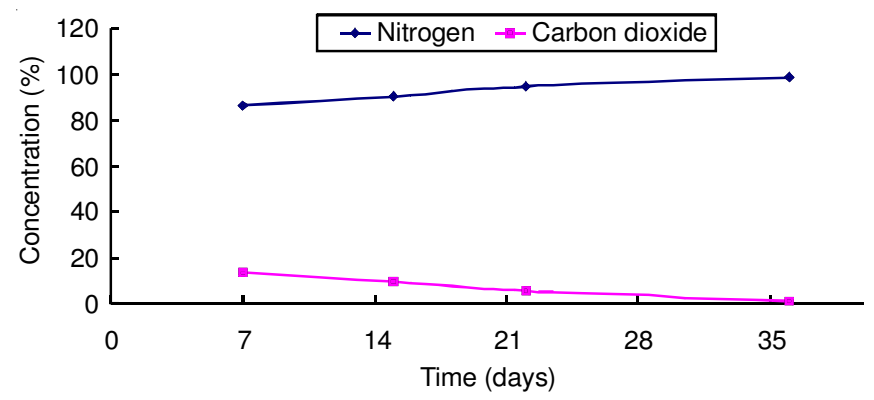

Fig. 6. (a) Concentrations of gaseous products from $\mathrm{A}_{2}$

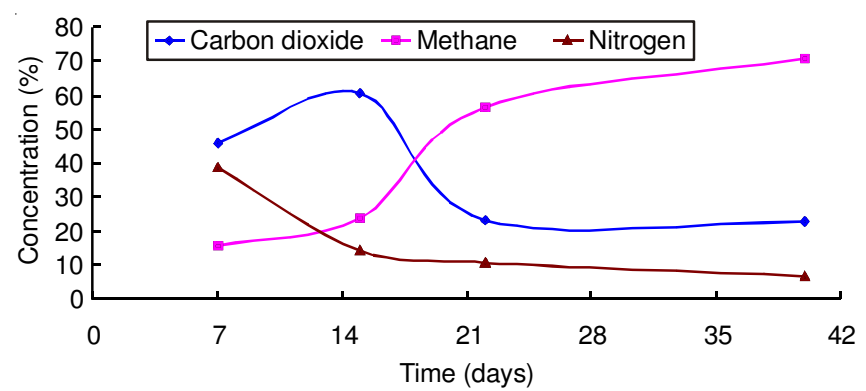

Fig. 6. (b) Concentrations of gaseous products from $\mathrm{B}_{2}$

Gases produced from $\mathrm{A}_{2}$ mainly consisted of $\mathrm{N}_{2}$ and $\mathrm{CO}_{2}$, of which $\mathrm{N}_{2}$ was on the rise above $90 \%$ with a dominant advantage over $\mathrm{CO}_{2}$ at a relative low and stable level, illustrating the whole-process impact of denitrifying bacteria. While $\mathrm{B}_{2}$ of Zhongtai generally witnessed two gas-production peaks during this period, in which $\mathrm{CO}_{2}$ gradually reached a peak at $60 \%$ first on the 15 th day with a recognizable higher concentration over $\mathrm{CH}_{4}$ before $\mathrm{CH}_{4}$ began to rise dramatically from the 18th day, when $\mathrm{CH}_{4}$ has replaced $\mathrm{CO}_{2}$ to be the dominant 


\begin{tabular}{cccccccccc}
\hline \multicolumn{8}{c}{ TABLE-6 } \\
\hline \multicolumn{8}{c}{ DATA OF X-RAY DIFFRACTION OF COAL SAMPLES } \\
\hline No. & $2 \theta_{002}\left({ }^{\circ}\right)$ & $2 \theta_{100}\left({ }^{\circ}\right)$ & FWHM $_{002}\left({ }^{\circ}\right)$ & FWHM $_{100}\left({ }^{\circ}\right)$ & $\mathrm{d}_{002}(\AA)$ & $\mathrm{L}_{\mathrm{a}}(\AA)$ & $\mathrm{L}_{\mathrm{c}}(\AA)$ & $\left.\mathrm{N}^{\circ}\right)$ \\
\hline $1 \#$ & 25.377 & 40.35 & 6.545 & 6.169 & 3.507 & 28.049 & 12.995 & 4.705 \\
$2 \#$ & 24.822 & 43.341 & 6.983 & 8.017 & 3.584 & 21.800 & 12.167 & 4.395 \\
\hline
\end{tabular}

gas since then till the very end. This indicates a fact that the denitrifying bacteria are quite active at the beginning owing to its shorter growth cycle than that of methanogens, which further can be evidenced by a constant decline of $\mathrm{N}_{2}$.

Analyses of solid products after fermentation: Sample $\mathrm{B}_{2}$ from Zhongtai was subjected to XRD (Table-6) before and after the fermentation and was numbered as $1 \#$ and $2 \#$, respectively.

The contrasts in the crystal parameters used to characterize the aromatic degree of coal samples were shown by a bar chart as portrayed in Fig. 6 .

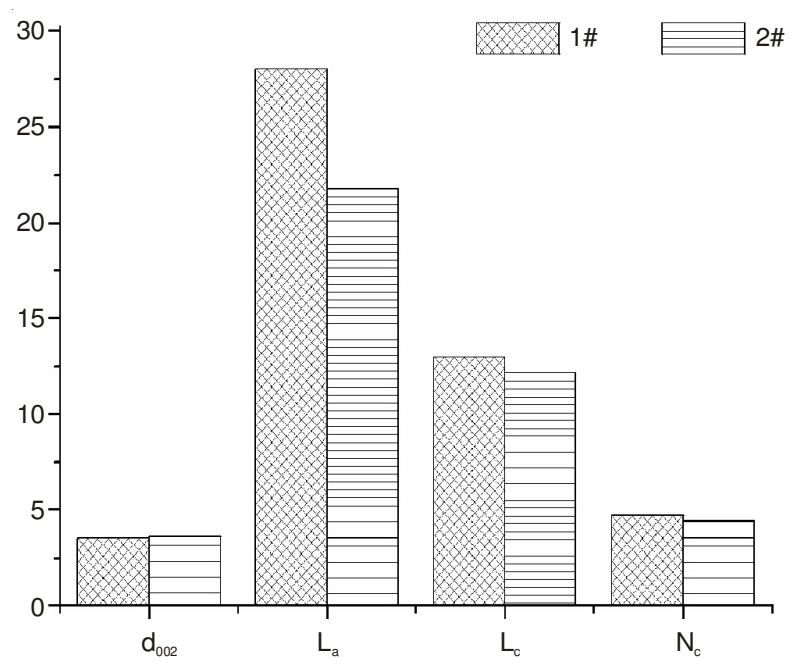

Fig. 7. Variations of crystal parameters

As can be suggested from Fig. 7, the small-molecule structures on the lateral chains of aromatic rings are mainly the targets of degradation rather than the macromolecules, while the degree of aromatization will see a slight drop at the same time, which can be evidenced by the signatures that $\mathrm{L}_{\mathrm{a}}$ was becoming smaller and the diffraction peak gradually shifted to a bigger $\theta$ side.

\section{Conclusions}

Through the experiments, these conclusions can be drawn as follows:

- An overhigh pH value and big amount of denitrifying bacteria in mine water of Shaqu are the major reasons for the absence of methanogens.

- Denitrifying bacteria can produce a big amount of $\mathrm{N}_{2}$, which results in the decline of the production of $\mathrm{CH}_{4}$, consumption of acidic metabolic products, secretion of alkaline substances and further the rise of $\mathrm{pH}$ values in solutions.
- Disodium EDTA is able to maintain the concentration equilibrium of heavy-metal ions in solutions so that a notable growth of $\mathrm{CH}_{4}$ can occur. However, when the concentration of disodium EDTA reaches an overhigh (more than $1.0 \mathrm{~g} / \mathrm{L}$ and over), the production will decrease due to the death of microbial.

\section{ACKNOWLEDGEMENTS}

This study is funded by the National Science Foundation of China (No. 41002047 and No. 40972109), Scientific and Technological Research projects of Henan province (No. 12A440005 and No. 132102210253 and No. 13A440335), the State Key Laboratory Cultivation Base for Gas Geology and Gas Control (Henan Polytechnic University) Open project (No. WS2012B05 and No. WS2013A12), Doctor Fund of Henan Polytechnic University (No. B2012-015), Youth Foundation of Henan Polytechnic University (No. Q2012-31).

\section{REFERENCES}

1. A.R. Scott, W.R. Kaise and W.B. Ayers, AAPG Bulletin, 78, 1186 (1994).

2. H.-L. Liu, C.-Y. Liu, H.Y. Wang, Y. Yang and J.-M. Li, Xinjiang Geology, 24, 149 (2006)

3. X. Hao, J. Hong and W. Gao, Guizhou Agricultural Sci., 35, 111 (2007).

4. A. Wang and Y. Qin, Coal Geology and Exploration, 38, 23 (2010).

5. D.P. Xia, X. Chen, X.B. Su and Y. Wu, Natural Gas Industry, 32, 107 (2012).

6. H. Lin, M. Sui and H. Wang, J. China Coal Society, 37, 1359 (2012).

7. P. Gerike and W.K. Fischer, Ecotoxicol. Environ. Saf., 3, 159 (1979).

8. B.D. Faison, In: D.L. Crawford, Microbial Transformations of Low Rank Coals, CRC (Chemical Rubber Company), pp. 1-26 (1992).

9. M. Li and Y. Zhang, Natural Gas Industry, 25, 487 (1998).

10. J. Liang, W. Guan, Y. Jiang, C. Xi, B. Wang and X. Li, Petroleum Exploration and Development, 39, 764 (2012).

11. Y. Zhou and X. Liao, J. Agri-Environ. Sci., 26(Supplement), 340 (2007).

12. D. Pang and H. Yang, China Animal Husbandry \& Veterinary Medicine, 37, 32 (2010).

13. W. Zhang, J. Kang and K. Wang, J. Xingyi Normal Univ. for Nationalities, 2, 113 (2011).

14. S.Y. Mao, Y. Su, C.F. Yang and W.Y. Zhu, Acta Microbiol. Sin., 51, 1390 (2011).

15. X.B. Su, X. Chen, H.F. Wang and D.P. Xia, Coal Conversion, 36, 16 (2013).

16. A. Wang and Y. Qin, J. China Univ. Mining Technol., 40, 888 (2011).

17. A.C. Alder, H. Siegrist, W. Gujer and W. Giger, Water Res., 24, 733 (1990).

18. M.L. Hinck, J. Ferguson and J. Puhaakka, Water Sci. Technol., 35, 25 (1997).

19. G. Tang, Q. Tang, J. Huang et al., J. Environ. Sci. (China), 29, 2345 (2008).

20. W. Ma, J. Tibbits and M. Adams, Chinese J. Soil Sci., 35, 56 (2004). 